https://doi.org/10.15407/ujpe67.1.88

\title{
MYKOLA OLEKSIYOVYCH AZARENKOV (to the 70th anniversary of his birth)
}

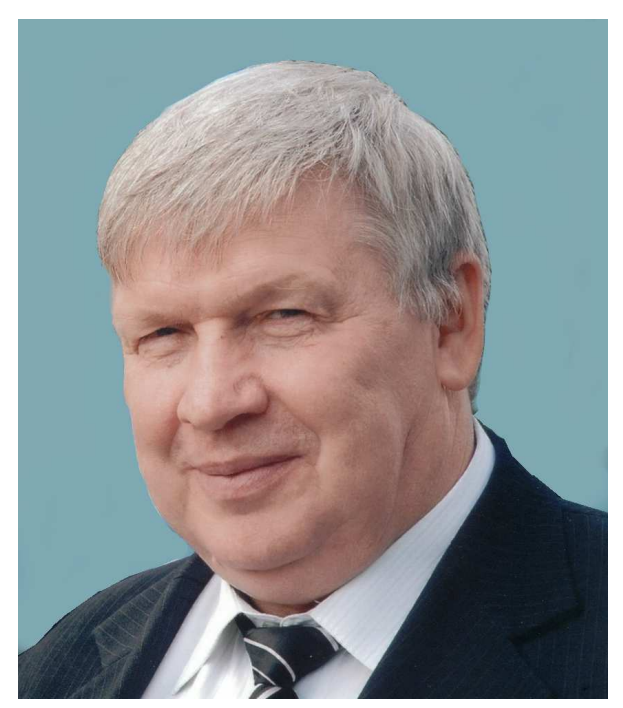

Leading Ukrainian scientist in the fields of plasma physics, radio physics, electronics, materials science, and nanomaterials, a winner of the K.D. Sinelnikov prize of the National Academy of Sciences of Ukraine (NASU), Honored Worker of Science and Engineering in Ukraine, Honored Professor of the V.N. Karazin Kharkiv National University, Professor of the Chair of Reactor Building Materials and Physical Technologies of the School of Physics and Technology (SPT) of the V.N. Karazin Kharkiv National University, Academician of the NASU Mykola Oleksiyovych Azarenkov celebrated his 70th birthday on December $15,2021$.

M.O. Azarenkov was born in 1951 in the village of Muravlinka (the Novovodolaz'kyi district of the Kharkiv region). In 1976, he graduated cum laude from the SPT of the Kharkiv State University (KhSU) in the specialty "Experimental Nuclear Physics" and was recommended for postgrad- uate studies at the KhSU in the specialty "Physics and Chemistry of Plasma". In 1980, he successfully completed his postgraduate studies and defended the $\mathrm{PhD}$ dissertation "Some issues of wave propagation and excitation in bounded plasma". In February 1983, he was elected an assistant of the Chair of General and Applied Physics (CGAP) of the KhSU. Since 1987, he was the Associate Professor, and, in 1992, he was elected the Professor of the CGAP. In 1991, M.O. Azarenkov defended his doctoral dissertation "Surface-type waves at the plasmametal interface". The academic ranks of Associate Professor and Professor of the CGAP were obtained in 1987 and 1994, respectively. Since 1996 and for more than twenty years, Mykola Oleksiyovych had worked as the Head of the Chair of Reactor Engineering Materials (since September 2012, the Chair of Reactor Engineering Materials and Physical Technologies) of the SPT of the KhSU. He worked as the Deputy Dean since 1988 till 1996 and, since 1996 till 2005, as the Dean of the SPT of the University. In 2001, the Institute of High Technologies was created, which included the Faculty of Computer Science, the SPT, and the Faculty of Physics and Energetics, and M.O. Azarenkov was appointed the Director of this institute. Since 2005 till 2021, he worked as a ViceRector of the Universuty for Research and Educational Affairs.

Mykola Oleksiyovych lectured general and special courses in general physics, mathematics, mathematical physics, plasma physics, and plasma electronics. Several times, he has been recognized as the best lecturer of the University. He is the author or co-author of more than 600 scientific and scientific-methodical works, including more than 10 review articles commissioned by editorial boards, as well as more than 40 books, textbooks, and manuals. M.O. Azarenkov

ISSN 2071-0194. Ukr. J. Phys. 2022. Vol. 67, No. 1 
made a substantial contribution to the study of the wave properties and nonlinear wave dynamics in bounded plasmalike media, to the development of radio physics and plasma electronics, to the theory of gas discharges, nuclear energy, nuclear physics methods in solid state physics, radiation materials science, nanotechnology, nanomaterials, etc. M.O. Azarenkov was a leader of more than thirty research projects in the framework of government and industry programs, as well as more than ten international grants. He was a research supervisor of seventeen $\mathrm{PhD}$ theses and a scientific adviser of seven doctoral dissertations. In 2006, he was elected Corresponding Member, and, in 2012, he became Academician of the NASU.

M.O. Azarenkov was elected the Vice-President of the Ukrainian Physical Society, the Deputy Academician-Secretary of the Department of Nuclear Physics and Power Engineering, the Deputy Chairman and the Chairman of the specialized scientific council. He was the chairman of the organizing committees and the jury of all-Ukrainian student and school olympiads in physics, tournaments of physicists, and competitions of student research papers. He is the Editor-in-Chief of the East European Journal of Physics included into the Scopus abstract and citation database, a member of the editorial boards of a number of journals and university bulletins, a Chairman of the expert commission on general physics of the Ministry of Education and Science of Ukraine, and a member of the physics section of the Committee of the State prizes of Ukraine in science and technology. Mykola Oleksiyovych was a council member of the State Foundation for Fundamental Research (now, the National Research Foundation of Ukraine), a Chairman and a member of the organizational and program committees of many international conferences, etc. He made a significant contribution to provide the university's acceptance to the European $\mathrm{Nu}$ clear Education Network. He initiated the creation of educational and scientific complexes with the institutions of the NASU and the academic scientific and educational complex "Resurs". He participated in the creation of the Innovation Center of the University and the technopark "Slobozhanskyi".
M.O. Azarenkov was awarded the state and branch awards. He is Honored Worker of Science and Engineering of Ukraine (2003) and a winner of the K.D. Sinelnikov prize of the NASU (2010). He was awarded the decorations of the Ministry of Education and Science of Ukraine: "Distinguished Worker in Education of Ukraine" (2000) and "For Scientific Achievements" (2010). He was awarded the Honored Diploma of the Presidium of the NASU (2005), the awards of the NASU "For Scientific Achievements" (2010), "For Education of Young Scientists" (2011), and "For Professional Achievements" (2015). He was also awarded the Honored Diploma of the Head of the Kharkiv Regional State Administration (2011), the Honorary Title "Honored Professor of V.N. Karazin Kharkiv University" (2008), and the university decorations: Rector's diplomas, the V.N. Karazin medal, and "For serving the Karazin University".

The scientific community, friends, colleagues, and numerous disciples of Mykola Oleksiyovych sincerely congratulate him on his 70th birthday and wish the inexhaustible vitality and fruitful longevity in the science and education.

O.S. BAKAI, YU.A. BEREZHNOI, V.M. BERESNEV, O.A. BIZYUKOV, V.A. BILOUS, L.A. BULAVIN, R.V. VOVK, I.YE. GARKUSHA, I.O. GIRKA,

D.L. GREKOV, M.I. GRYSHANOV, I.B. DENYSENKO, I.M. KARNAUKHOV, V.O. KATRYCH, V.F. KLEPIKOV, A.M. KONDRATENKO, O.YU. KORCHYN,

V.M. KUKLIN, V.T. LAZURYK, S.V. LYTOVCHENKO, V.O. LISOVSKYI, M.O. MCHEDLOV-PETROSYAN, I.M. NEKLYUDOV, V.P. OLEFIR, I.M. ONISHCHENKO, V.G. RUDYCHEV, V.I. SLISENKO,

YU.V. SLYUSARENKO, V.YU. STORYZHKO, V.I. TKACHENKO, V.O. CHYSHKALA, M.F. SHUL'GA

On behalf of the Editorial Board of the Ukrainian Physical Journal, we also congratulate Mykola Oleksiyovych with his anniversary!

Editor-in-Chief of UJP,

Academician of the NASU

A.G. ZAGORODNY 